\title{
Promoting Autonomous Learning Through Mobile Applications in a Blended English Language Classroom
}

\author{
Isna Rakhmawati \\ Faculty of Education and Teacher Training \\ UIN Sunan Ampel Surabaya \\ Surabaya, Indonesia \\ isnarakhmawiguno@gmail.com
}

\begin{abstract}
Mobile Assisted Language Learning (MALL) has been widely implemented by language teachers to succeed lessons in this vast access on technology. However, it is not a simple idea to put into practices due to the lesson preparation, size of the classes and time constrains. Therefore, teachers can also make use of MALL in a blended English language classroom as an alternative to promote effective and autonomous learning environment. A case study was employed to investigate the implementation of MALL in a writing class at the university level majoring on English language education. The stages involved in this study are, namely: 1) identifying the phenomenon, 2) identifying the research participants, 3) generating hypotheses, 4) collecting data, 5) analyzing data, and 6) interpreting data. Twenty-one students were assigned to participate in this research. The result of this study showed that MALL could bring positive vibes in language learning. In addition, learners were more communicative, independent and confident in composing their writing. The features in some mobile applications allowed students to submit paperless assignment. Surprisingly, there were also some glitches when using MALL in a blended English language classroom such as troubles on the Internet connection that caused delayed on the assignment submission.
\end{abstract}

Keywords: MALL, autonomous language learning, blended English language classroom

\section{INTRODUCTION}

The emerging of technology-supported tools for English language learning is rapidly growing. There are various kinds of learning tools that can be effectively used for the English teaching and learning purposes such as computer software, online websites, tablet, mobile device applications, etc. The tools have been countless support systems to integrate the learning goals into the teaching and learning practices. Learning English becomes fun learning vibes for both students and teachers because of the use of learning platforms or applications. Students enjoy most of the learning activities that are structured into the online modules.

To some great extent, the online modules in assisted language learning (MALL) get learners more engaged into the language environment. They can control their own language learning process and progress based on their own cognitive state [1]. They already know what to study by accessing the online modules, doing the tasks from the teachers, and submitting their assignment online based on the deadline. They can keep up with the deadline while studying face-toface with the teachers in the classroom. When they have technical problems such as error features on the mobile app, students can always ask questions from the teachers or classmates either offline or online.

Allowing students to ask questions and giving the rest of the students opportunities to answer questions make both of the offline and class lively. The communication is even richer and effective in both ways particularly when they deal with writing tasks. Writing tasks take a longer process starting from pre-writing, drafting, sharing, revising, editing, publishing and assessing [2]. Students put much effort to finally come to the publishing stage. In fact, a preliminary study conducted in an English language department shows that every writing stage always has its challenge due to some factors.

The first factor is that students feel that writing task is such a tough process. They think that it is hard to come up with the ideas about what to write even though there are topics provided by the lecturers. They confessed about lack of reading habit and were unfamiliar with the topics given. Therefore, they were required to start researching about the topics by getting some information through reading some references. It also took a long time to find the most relevant references on the topic, so that they also requested some guidance from the lecturers.

The second factor is that students had a hard time to put the ideas together into good paragraphs. They began their confusion to arrange their paragraphs with the choice of vocabulary. They did not have enough vocabulary to compose their writing. Even, they use Google translate, it still sounded like translation machine. Consequently, they were uncertain with their sentences. Besides that, they were also anxious about their grammar mistakes. It became harder to structure the sentences into a comprehensible composition. They admitted that it was difficult to swift the paragraphs flawlessly from one to another paragraph.

The third factor is that students were less confidence with their writing composition. The complexity in the process of writing effect the students' self-assurance so much. They had the tendency that their paragraph writing was weak, 
unstructured and awful. As a result, they were afraid to submit their work and get feedback from the lecturers. It was shameful for them because they got many corrections on their writing. Mostly, they felt discouraged and were unwilling to revise their work. The other factor is on the time constraint. It has always been traumatizing for teachers to manage the time for delivering the concept of how to teach a better writing and keeping up the students with writing practices.

Previous studies by reference [1] revealed that MALL could be implemented for learning vocabulary, listening, grammar, pronunciation, speaking and reading. Another study conducted in United Arab Emirates showed that reading materials had been effectively and broadly used for online language learning, but writing materials were the least existing instructional online mobile app [3]. Seeing the facts that online learning was effectively used for language learning, the least number of online writing materials in mobile app and also students faced some problems in writing as well as teachers concerned on the time management to teach writing, the present study intends to investigate the use of mobile applications as a tool to help students learn how to compose a better writing and assist teachers how to manage the materials and students writing practices in blended learning classroom.

\section{THEORETICAL FRAMEWORK}

\section{A. Writing Process}

Writing is a complex process that urges the students to really understand about what they write, why they put such ideas in their writing draft, and how they structure the sentences into a complete thought in paragraphs. The nature of writing basically involves a mental process [4]. Writing is the final product of receptive and productive skills in the form of written language. Writing is the written form of spoken language. Since it is written, students need to focus on how to generate ideas, organize the ideas into coherent sentences, use discourse markers and rhetorical conventions to structure cohesive written text, revise text for a clearer meaning, edit text for appropriate grammar and finally produce a final writing product [5].

The students' final writing product unlikely does not come up effortlessly. Students face some difficulties in writing process such as linguistic, cognitive, and phycological problems [6]. Students have different linguistic proficiency. They pay less attention on choosing the most appropriate vocabulary, organizing the sentences grammatically and connecting sentences with correct cohesive devices. Furthermore, writing problems also arise in students' cognitive aspects. Some writing topics are challenging due to lack of background knowledge. They hardly structure their ideas into comprehensive and effective content because they rely on L1 too much [7]. The other issue results from students phycological factor. Students find writing tasks as burdens. They keep complaining on the process and seem obscured about their writing.

The writing process should go through some stages to lessen students' millstone. Ref [2] recommends seven writing stages, namely: 1) pre-writing, 2) drafting, 3) sharing, 4) revising, 5) editing, 6) publishing and 7) assessing. Pre-writing is aimed to help students explore the topic. Various activities can be implemented in pre-writing by scaffolding the students to get relevant information about the topic. Using pre-writing material students can go to drafting stage. Teachers can also encourage students to check their draft using mobile applications. Students put every relevant idea in their draft then share with partners, small groups or whole class. The sharing stage is supposed to be enjoyable and helpful for students before they come to revising stage.

Revising, editing and publishing stage is the key to a writing task. Revising draft is not a tough process when students get regular feedback from their peers or teachers. Then, they can go to editing phase by considering the feedback as well as making corrections on their oversight writing. After they finish editing, they finally go to publishing part. This part is a rewarding experience for the students as they get to present their writing class presentation, web site, platform or portfolio. The last stage is done by teachers to assess students' writing based on the criteria of a good writing. The whole writing stages can also be done efficiently with available mobile applications.

\section{B. Mobile-assisted Language Learning (MALL)}

Mobile-assisted Language Learning (MALL) has been promoted recently to cut down the barriers on language teaching and learning. MALL can also enable students become more active, autonomous and collaborative because they contribute to their own learning path [8]. Students nowadays are digital natives [9]. They have extensive access on mobile phones because its portability. They use mobile phones for several purposes such as browsing, connecting on social media, or playing online game. They can spend many hours to stare at their mobile phones. Teachers should take an advantage on the students' extensive use of smartphone for instructional use of language learning.

There are choices of mobile applications for instructional use of language learning to assist both students and teachers in developing writing skills. Study conducted by reference [10] revealed that grammar clinic mobile application raised students' metalinguistic awareness and improve students' selfediting ability to write in English. Students perform better in writing their final draft because they can immediately check their writing through mobile apps and correct it right away. In fact, teachers are benefitted to correct the students' grammar errors. Teachers save more time to focus on the students' writing content rather than grammar checking.

There is also another mobile application that serves as a teacher helper to collect the students writing in an online platform such as Schoology. Schoology offers various kinds of educational-based features such as document and multimedia sharing, discussion forum, announcements and updates, assignment and assessment [11]. Students can go through the stages of sharing, revising, editing, publishing their writing using Schoology. They can use Google docs to draft their writing and share the link through Schoology for sharing sessions. These features are great tools to conduct writing activities in a blended learning setting.

\section{Blended Learning}

Blended learning is defined as an integration of face-to-face classroom and online learning instruction [12]. The idea of blended learning in writing course fits in the needs of students and teachers to meet in classroom for pre-writing, drafting and sharing activities. The rest activities such as revising, editing, 
publishing and assessing can be done online using mobile applications. However, there is a combination of face-to-face and online learning within the pre-writing, drafting and sharing activities. For example, students accessed Answerthepublic.com for brainstorming the topics through their smartphone and jot down in Canva application to proceed to drafting stage. The possibility to incorporate mobile apps in writing stages is likely high in blended learning.

Blended learning is also feasible for effective and convenient collaborative learning [13]. Students could interact and share opinions about their writing tasks with their classmates through mobile apps even when they are outside the classroom. The teacher encouraged students to review their classmates' writing draft and comment on the strengths as well as weaknesses. During sharing session, teachers should scaffold how to comment and give feedback on the students' draft. The feedback from classmates is used to revise their writing draft before submitting the final draft to the teachers. On the revision stage, students should also double check their writing face-toface to the teachers. After the teachers check students' writing, students edit their final draft and submit to the teachers online.

The arrangement of students writing activities in blended learning should also follow a framework of RASE learning design [14]. RASE stands for Resources, Activity, Support, and Evaluation. Resources in writing course are varied from lectures' note in the form of power point, e-books, graded writing activities, and videos on Coursera. Students can access the resources on the online platform such Schoology, Canvas.intsructure.com or Moodle. Activities in writing include pre-writing, drafting, sharing, revising, editing, and publishing. Supports are provided through the Internet connectivity and teachers scaffolding. Lastly, the evaluation is conducted to assess and give direct corrective feedback to students writing final draft.

\section{METHOD}

To investigate the use of mobile applications in blended writing course, the researcher conducted a case study in her own English writing class. Case study research design focuses more to the documentation and analysis of a single instance or particular groups' behavior [15]. The researcher intended to find out the students' behavior changes after using mobile applications in English writing course. The setting documentation is in blended English writing class. The qualitative study can further straighten how students' writing skills can be improved using mobile applications.

The research procedures begin with: 1) identifying the phenomenon, 2) identifying the research participants, 3) generating hypotheses, 4) collecting data, 5) analyzing data, and $6)$ interpreting data [16]. An undergraduate English writing course in English Language Department in Islamic State University of Surabaya were selected as the research participants. The study was conducted in even semester of academic years of 2018-2019. The course adopted blended learning model consisting face-to-face and online learning activities. The researcher collected the data both in face-to-face and online learning.

The face-to-face learning conducted in classroom. Students went through the process of pre-writing, drafting and sharing in class. Furthermore, they were also assigned to use mobile applications at this stage to brainstorm the topic in pre-writing such as Answerthepublic.com, Canva and relevant resources either e-book or online blogs. Google docs app was used to make the writing draft. Another app could also be used to paraphrase sentences such as Quilbot.com. Later, the online draft could be reviewed and edited by the classmates during sharing session in small groups. They were also assigned to have Schoology account to access the class resources and shared their works as well as gave feedback.

Giving direct corrective feedback was done face-to-face in class and online through Schoology platform. The learning process continued to online learning for revising, editing, publishing and assessing stages. Students used Google docs, Quilbot.com, Grammarly for revising. They also edited their writing draft in online proofreader website through their mobile phone or computer. Teachers also allowed the students to communicate using WhatsApp to get feedback on the writing or fix the technical problems. Then, the final draft was submitted and published on Schoology platform. Teachers finally graded the students final draft and published the grade as well as the feedback on the platform. Grading system was developed on rubistar.org for every genre of writing in the course.

When the grading was done, the researcher put the data into category of 1) pre-writing, 2) drafting, 3) sharing, 4) revising, 5) editing, 6) publishing and 7) assessing. The researcher recorded every students' writing activities, progress and selected what significant changes of students' behaviors. To strengthen the credibility of the data, the researcher applied triangulation method by conducting an interview to the research participants who had the same experiences in using mobile app for writing course in blended English classroom.

The next research procedure is analyzing and interpreting the data by drawing conclusion and writing research report descriptively from learning analytic in a Schoology. Learning analytic was useful data statistics to course materials and students' performance. The students' total hits per day in the writing course on Schoology were also collected as research data such as last log in, last course access, total time in course, number posts in discussion forum, on time submission and assignment description.

\section{FINDINGS AND DISCUSSION}

Some striking findings were discovered on the use of mobile applications for writing course in blended English classroom. Writing course which was mostly troublesome for students turned out to be enjoyable because of the mobile apps. They could access some mobile applications such as Answerthepublic.com, Canva, and AnkiDroid for pre-writing. The pre-writing activities were conducted both face-to-face and online learning. Before they came to class for face-to-face session, they were assigned to read materials in the form of ebooks, power point slides, websites and videos on their Schoology account. The materials were structured into graded modules that should be accessed each week. Surprisingly, they brought some issues about the online materials in the classroom. Teachers and students discussed the components of good writing and brainstormed about writing topics in class sessions. 
Students proceeded to drafting stage subsequently when they already designed their topic outline on Canva. They started to write their draft using Googledocs and Quilbot.com to check their phrases from the primary resources. Moreover, using AnkiDroid app, Thesaurus and offline dictionary for checking relevant vocabulary was also done by students. Teachers and students shared ideas and edited the writing draft collaboratively through Googledocs link in the sharing stage online and offline. Mostly, students could catch the ideas better on what to edit if they could sit down together with the teachers and received direct corrective feedback. Students improved their writing accuracy in their revision after receiving direct corrective feedback [17]. They edited their draft based on their groups' comments and teachers' feedback. They also doublechecked by inserting draft into free online website such as analyze.academichelp.net to proofread. Grammarly app was such a big helper for students to fix their grammar error on the revision.

The students' automatic correction on their revision and access to the online learning platform using mobile applications promote autonomous language learning environment. $\mathrm{M}$ Learning platform helped students activate their autonomy in learning language [18]. They freely chose what materials to read, gave comments on their classmates' work, got feedback from teachers and kept updated with the task submission deadline. They also worked collaboratively with their peers or groups to revise their draft because teachers encouraged peeror group review before submission. In addition, it was more time-saving and environmentally friendly for teachers to review all the students work in platform.

M-learning platform such as Schoology also enabled students published their final draft. They attached their final draft link from Googledocs and hit submit button before the deadline. Students were mostly on-time. There were two students who were frequently 1-day late in submission. They said that they had problem on the Internet connection. They waited all night to upload the final draft file and failed. Teachers gave an alternative for students to submit final draft through WhatsApp if they could not upload it in Schoology. After that, teachers assessed the students' work using a scoring rubric from Rubistar and published the final grade through Schoology. Students were mostly satisfied with their grade and motivated to complete the following writing tasks.

\section{CONCLUSION}

The use of mobile applications in blended English writing classroom has some advantages and drawbacks. Students were more engaged to writing activities using mobile applications. They felt confident enough drafting their final draft after going through the seven stages of writing such as pre-writing, drafting, sharing, revising, editing, publishing and assessing. Besides that, they were more communicative because they could write collaboratively as well as exchanging comments on their writing tasks both face-to-face and online through Schoology. Students could control their own learning path since they were able to access the tasks online through their mobile app at anytime and anywhere. Therefore, there were more autonomous and responsible for their tasks completion. Moreover, teachers could watch the students' writing skills progress because there was learning analytic feature on
Schoology. Grading was so much easier using Rubistar and Schoology grading system.

Despite the advantages of using mobile applications for writing course in blended learning, there were some drawbacks also outweighed the writing process. The first issue was on the Internet connection. Students spent a lot of data usage to join the learning platform, but the connection did not perform well. They complained about the online submission troubles. The submit button remained error when the connection was slowing down and many students accessed their dashboard in the same time. The second issue was about the small mobile phone screen. The students hardly read the writing materials when their eyes got tired. To overcome these problems, students were recommended to connect their mobile hotspot to their laptop which has a bigger screen.

\section{REFERENCES}

[1] T.M. Miangah and A. Nezarat, "Mobile-Assisted Language Learning," in International Journal of Distributed and Parallel Systems (IJDPS), vol. 3, pp. 309-319, January 2012.

[2] S. Peha, An Introduction to Writing Process: Tools and Techniques for Helping Students Turn Raw Ideas into Polished Prose. Teaching that Makes Sense, Inc, 2003.

[3] S.S. Janeen, and A.J. Thomas, "Effectiveness of Online Language Learning," in Proceedings of WCECS, vol. I, October 2015.

[4] M. Cohen, and M. Riel, "The Effect of Distant Audiences on Students' Writing," in American Educational Research Journal, 1989.

[5] H.D. Brown, Teaching by Principles: An Interactive Approach to Language Pedagogy, $2^{\text {nd }}$ Ed. White Plains, NY: Longman, 2001.

[6] D. Byrne, Teaching Writing Skills. Singapore: Longman. 1995.

[7] M. Fareed, A. Ashraf, and M. Bilal, "ESL Leaners Writing Skills: Problems, Factors and Suggestions," in Journal of Education and Social Sciences, vol 4(2), pp. 81-92, 2016.

[8] D. Haven and A. Palalas, "Reconceptualizing Design Approaches for Mobile Language Learning," in CALICO Journal, vol. 28, pp. 699-720, May 2011.

[9] M. Prensky. Digital Game-based Learning. St. Paul, MN: Paragon Hous. 2007.

[10] Z. Li and V. Hegelheimer, "Mobile-Assisted Grammar Exercise: Effects on Self-Editing in L2 Writing," in Language Learning \& Technology, vol. 17, pp. 135-156, October 2013.

[11] G.K.W. Wong, "A New Wave of Innovation Using Mobile Learning Analytics for Flipped Classroom," cited in D. Churchill, J. Lu, T.K.F. Chiru, and B. Fox, Eds. Mobile Learning Design: Theories and Application. Singapore: Springer, 2016.

[12] W.T. Al-Ani, "Blended Learning Approach Using Moodle and Students'Achievement at Qaboos University in Oman," in Journal of Education and Learning, vol 2, pp. 96-110, 2013.

[13] S. H. Jin, "Implementation of Smartphone-based Blended Learning in an EFL Undergraduate Grammar Course, “ in KAMALL, vol 17, pp. 11-35, 2014.

[14] D. Churchill, M. King, and B. Fox, "Learning Design for Science Education in the $21^{\text {st }}$ Century, " in Journal of the Institute for Educational Research, vol. 45, pp. 404-421, 2013.

[15] D. Nunan, Research Methods in Language Teaching. New York: Cambridge University Press, 1992.

[16] J.W. Creswell, Educational Research: Planning, Conducting, and Evaluating Quantitative and Qualitative Research (4th Edition). Boston, MA: Pearson Education, 2012.

[17] C.G.V. Beuningen, N.H.D. Jong, and F. Kuiken, "The Effect on Direct and Indirect Corrective Feedback on L2 Learners Written Accuracy, " in 


\section{PRESS}

ITL International Journal of Applied Linguistics, vol. 156, pp. 279-296, December 2008.

[18] A. Priyatno, "Promoting Learner Autonomy through Schoology MLearning PLatform in EAP Class at an Indonesian University," in
IATEFL Poland Computer Special Interest Group and the University of Nicosia, vol. 17, pp. 55-76, April 2017. 